\title{
Analisis Yuridis Unsur Ignorantia Legis Excusat Neminem Dalam Kasus Pembakaran Mayat Di Kecamatan Sanden Bantul Yogyakarta
}

\author{
Nindya Nursari I S \\ Universitas PGRI Yogyakarta \\ nindyanursari97@gmail.com
}

\begin{abstract}
ABSTRAK
Penelitian ini bertujuan untuk mengetahui unsur Ignorantia Legis Excusat Neminem (ketidaktahuan tentang hukum) yang terdapat dalam fiksi hukum, jika diterapkan dalam kasus pembakaran mayat yang terjadi Sanden Bantul Yogyakarta.

Metode penelitian ini menggunakan kualitatif deskriptif. Adapun tempat penelitian dilakukan di Polres Bantul dan Pengadilan Negeri Bantul, penelitian dilakukan pada bulan Maret sampai Mei 2019. Subjek dari penelitian ini dua orang yaitu Penyidik dari Polres Bantul dan Hakim Pengadilan Negeri Bantul. Teknik analisis data yang digunakan adalah dengan mereduksi data yang diperoleh, kemudian menyajikan data yang mempunyai hubungan dengan judul penelitian. Keabsahan data menggunakan triangulasi teknik untuk menguji kredibilitas data dan dilakukan dengan cara mengecek data kepada sumber yang berbeda dengan teknik yang sama.

Hasil penelitian menyimpulkan bahwa unsur Ignorantia Legis Excusat Neminem (ketidaktahuan tentang hukum), bukan menjadi alasan untuk meringankan atau membebaskan pelaku dari tuntutan hukum, yang dapat membebaskan pelaku jika tidak bisa mempertanggungjawabkan perbuatannya, contohnya adalah orang gila dan yang dapat meringankan adalah pertimbangan hakim, selain itu kekuasaan hakim dapat meringankan penahanan pelaku dengan menggunakan sisi kemanusiaannya. Unsur Ignorantia Legis Excusat Neminem bagian dari fiksi hukum menandakan masih kurang maksimalnya penyebarluasan aturan perunang-undangan kepada masyarakat, karena masih ada warga masyarakat yang melakukan kejahatan, berpangkal dari ketidaktahuannya tentang hukum. Seperti kasus yang terjadi di Sanden Bantul tentang pembakaran mayat ini.
\end{abstract}

\section{Kata Kunci: Ignorantia Legis Excusat Neminem, Pembakaran Mayat, Fiksi Hukum}




\title{
Juridical Analysis of Ignorantia Legis Excusat Neminem Elements in Corpse Burning Cases in Sanden District, Bantul, Yogyakarta.
}

\author{
Nindya Nursari I S \\ Universitas PGRI Yogyakarta \\ nindyanursari97@gmail.com
}

\begin{abstract}
This study aims to determine the elements of Ignorantia Legis Excusat Neminem (ignorance of the law) contained in legal fiction, if applied in the case of the burning of bodies that occurred in Sanden Bantul, Yogyakarta.

This research method uses descriptive qualitative. The place of research was conducted in Bantul District Police and Bantul District Court, the study was conducted in March to May 2019. The subjects of this study were two people, namely Investigators from Bantul Regional Police and Bantul District Court Judges. The data analysis technique used is by reducing the data obtained, then presenting data that has a relationship with the research title. The validity of the data uses triangulation techniques to test the credibility of the data and is done by checking data to different sources with the same technique.

The results of the study concluded that the element Ignorantia Legis Excusat Neminem (ignorance of the law), is not an excuse to relieve or free the perpetrators of lawsuits, which can free the perpetrators if they cannot account for their actions, for example, crazy people who can alleviate judges, besides the power of judges can alleviate the detention of perpetrators by using their humanity side. The element of Ignorantia Legis Excusat Neminem, part of legal fiction, indicates that there is still a lack of maximum dissemination of regulations to the public, because there are still people who commit crimes, stemming from their ignorance of the law. Like the case that occurred in Sanden Bantul about burning this corpse.
\end{abstract}

Keywords: Ignorantia Legis Excusat Neminem, Cremation, Legal Fiction 


\section{PENDAHULUAN}

Unsur Ignorantia Legis Excusat Neminem dalam ilmu hukum diartikan bahwa ketidaktahuan dalam Undang-Undang (hukum), dalam beberapa literatur Ignorantia Legis Excusat Neminem dikenal sebagai fiksi hukum. Dalam teorinya fiksi hukum beranggapan bahwa saat norma hukum diberlakukan, maka disaat itu semua orang dianggap tahu hukum. Implementasi teori Fiksi Hukum ada dalam UU Nomor 12 tahun 2011 tentang Pembuatan Peraturan Perundang-Undangan, yang terdapat dalam pasal 81, sebagai salah satu yang mengatur substansi tentang pengundangan. Pasal 81 yang berbunyi "Agar setiap orang mengetahuinya".

Pengimplementasian tentang teori fiksi hukum ini, dapat dipahami dalam pemahaman hukum, masyarakat dianggap tahu hukum. Kondisi ini sebenarnya cukup memprihatinkan manakala banyak timbul kasus-kasus hukum yang berpangkal justru dari ketidakpahaman masyarakat tentang hukum yang berlaku, bahkan lebih jauh lagi ketidaktahuan masyarakat akan adanya peraturan perundang-undangan yang mengatur tentang apa yang disangkakan atau dituduhkan kepada anggota masyarakat yang terjerat aturan hukum.

Contoh kasus terhadap unsur Ignorantia Legis Excusat Neminem, yakni terjadi di Kecamatan Sanden Bantul Yogyakarta. Telah terjadi pembakaran terhadap mayat seseorang di Sanden Bantul Yogyakarta. Menurut keterangan pelaku, pelaku tidak tahu bahwa perbuatannya telah melanggar hukum, dari hal perbuatannya telah melanggar KUHP Pasal 170. Pelaku membakar mayat dengan dalih kremasi, karena perbedaan budaya Bali dan Yogyakarta. Hukum di Indonesia masyarakat telah diikat oleh asas fiksi hukum dimana menggangap bahwa semua orang tahu hukum (presumptio iures de iure).

\section{KAJIAN PUSTAKA}

\section{Pertimbangan Yuridis}

Hakikat pada pertimbangan yuridis hakim merupakan pembuktian unsur-unsur dari suatu delik, apakah perbuatan terdakwa memenuhi dan sesuai dengan delik yang didakwaan oleh penuntut umum putusan hakim (Lilik Mulyadi, 2007: 193). Pertimbangan Hakim dibagi menjadi dua, pertimbangan yuridis dan non-yuridis. Pertimbangan yuridis adalah pertimbangan hakim didasarkan pada fakta-fakta yuridis 
yang terungkap dalam persidangan oleh Undang-Undang dan dimuat dalam putusan. Pertimbangan non-yuridis dilihat dari latar belakang, akibat perbuatan terdakwa, kondisi, dan agama terdakwa (Rusli Muhammad, 2007: 212-221).

\section{Hukum sebagai Norma}

Adanya hukum yang berfungsi sebagai norma untuk mengatur antar anggota masyarakat membuat manusia terikat dengan kewajiban dan tanggungjawab hukum. Keterikatan pada hukum sebagai norma perilaku menjadi penting, karena ikatan moral saja tidak cukup sebagai jaminan untuk membangun kerjasama yang saling menguntungkan di tengah keberagaman kepentingan (Andre Ata Ujan, 2009: 29).

Tujuan hukum ialah mengatur pergaulan hidup secara damai. Perdamaian manusia dipertahankan dengan melindungi kepentingan-kepentingan golongan daripada pribadi. Tetapi kedua kepentingan tersebut selalu bertentangan, dan pertentangan ini menyebabkan pertikaian, dalam pertikaian ini hukumlah yang bertindak menjadi penengah untuk menciptakan perdamaian (Van Apeldoorn, 2011: 10-11).

\section{Indonesia Sebagai Negara Hukum}

Konsep Negara hukum Pancasila bersumber dari nilai-nilai sosial budaya Indonesia yang kristalisasinya adalah Pancasila sebagai Dasar Negara sebagaimana tertuang dalam Pembukaan UUD 1945. Sehingga sistem hukum dan politik hukum di Indonesia haruslah berdasarkan Pancasila, guna menetapkan hukum yang sesuai atau bertentangan dengan Pancasila (Jurnal Aloysius R. Entah, 2016: 539).

Indonesia menjalankan negara hukum melalui prinsip negara hukum pada umumnya yaitu adanya unsur perlindungan hak asasi manusia, adanya unsur pembagian kekuasaan, unsur pelaksanaan kedaulatan rakyat, unsur penyelenggaraan pemerintahan yang didasarkan pada peraturan perundang-undangan yang berlaku dan adanya peradilan administrasi negara (Jurnal Haposan Siallagan, 2016: 136). Secara umum bahwa Negara Kesatuan Republik Indonesia adalah Negara Hukum Pancasila atau Negara Hukum yang berdasarkan Pancasila yang mempunyai ciri-ciri berbhineka bukan Negara Sekuler, Negara Agama dan bukan Negara Atheis, tetapi Negara yang berdasarkan Ketuhanan Yang Maha Esa yang bersifat universal (Jurnal Aloysius R. Entah, 2016: 537). 


\section{Teori Fiksi Hukum (Ignorantia Legis Excusat Neminem): Konteks Ke Indonesiaan}

Teori fiksi hukum beranggapan jika suatu peraturan perundang-undangan sudah diberlakukan, seketika semua orang dianggap tahu. Ketidaktahuan seseorang akan hukum tidak dapat membebaskan orang dari tuntutan hukum, yang sering dikenal dalam bahasa Latin sebagai ignorantia iuris neminem excusat atau dalam bahasa Inggris "ignorance is no defense under the law" (Ronald Dworkin, 2006: 223).

Tidak ada alasan bagi pelanggar hukum untuk menyangkal tuduhan, dan alasan ketidaktahuan hukum atau peraturannya bukan alasan pemaaf atau membebaskan pelaku. Fiksi dipahami dari sudut pembentuk undang-undang, dengan tujuannya perumusan undang-undang yang singkat, dan menjadi alat untuk menghemat jumlah peraturan dan pengertian (http://khtibwriteinc. blogspot.com/2008/03/menggali-maknaperistilahan-hukum-dalam.html diunduh pada tanggal 29 Desember 2018).

\section{Unsur-Unsur Tindak Pidana Pembakaran}

Unsur tindak pidana pembakaran terbagi menjadi 3, yaitu unsur barangsiapa, unsur dengan sengaja membakar, dan unsur mendatangkan bahaya untuk umum dan barang (mayat). Unsur dengan sengaja membakar memiliki makna adanya nilai atau rencana yang dilakukan untuk membakar (Skripsi Andi Anugra, 2013: 58-61).

\section{Tindak Pidana Kekerasan yang Dilakukan Secara Bersama-sama Terhadap Orang Di muka Umum}

Menurut Hazawinkel-Suringa Hoge Raad Belanda mengemukakan dua syarat jika turut melakukan tindak pidana, yaitu: pertama, kerja sama yang disadari antara para pelaku, yang merupakan suatu kehendak bersama diantara mereka. Kedua, mereka harus bersama-sama melakukan kehendak itu. (Wirjono Prodjodikoro, 2003: 123).

Pengertian tindak pidana dengan terang-terangan dan tenaga bersama melakukan kekerasan (pengeroyokan) yaitu dalam Kitab Undang-Undang Hukum Pidana, tindak pidana pengeroyokan diatur dalam Pasal 170 KUHP. Kata "terang-terangan" dapat dikatakan di hadapan publik. Dalam Pasal 170 ayat (1) KUHP dijelaskan bahwa terangterangan dalam pengertian tidak bersembunyi, artinya tidak perlu di muka umum tetapi cukup apabila tidak diperlukan apa ada kemungkinan orang lain dapat melihatnya atau dalam suatu rumah dan publik melihatnya. Termasuk kejahatan terhadap ketertiban umum (Soenarto Soerodibroto, 2019: 105). 
Kata "penyertaan" dalam Kamus Besar Bahasa Indonesia berarti proses, cara, perbuatan menyertakan atau perbuatan ikut serta (mengikuti). Kata "penyertaan" berarti turut sertanya seseorang atau lebih pada waktu seorang lain melakukan suatu tindak pidana (Wirjono Prodjodikoro, 2003: 117). Kekerasan yang terdapat dalam Pasal 170 KUHP termasuk kekerasan terbuka dimana kekerasan tersebut dilakukan oleh seseorang ataupun beberapa orang melakukan kekerasan secara fisik yang dilakukan di tempat dimana dapat diketahui atau dilihat oleh publik (Thomas Susanto, 2002: 34).

\section{Pasal 181 KUHP}

D. Simons membedakan 2 unsur-unsur tindak pidana yaitu unsur obyektif dalam tindak pidana meliputi perbuatan orang, akibat yang kelihatan dari perbuatan itu, mungkin ada keadaan tertentu yang menyertai perbuatan itu seperti di muka umum pada Pasal 181 KUHP. Sementara itu, unsur subjektif dalam tindak pidana itu mencakup, orang yang mampu bertanggung jawab, adanya kesalahan (Sudaryono dan Natangsa Subakti, 2005: 115). Pasal 181 KUHP terdapat beberapa unsur, yaitu unsur barangsiapa, unsur "mengubur, menyembunyikan, membawa lari, atau menghilangkan mayat, dan unsur "dengan maksud hendak menyembunyikan kematiannya. (Jurnal Heppi Florensia, 2015: 20).

\section{METODE PENELITIAN}

Penelitian ini dilakukan di Polres Bantul dan Pengadilan Negeri Bantul. Pada penelitian ini, peneliti menggunakan metode penelitian kualitatif. Penelitian kualitatif dilakukan untuk memperoleh jawaban mengenai suatu fenomena tertentu di dalam masyarakat. Data yang akan digunakan adalah data primer, data sekunder dan data tersier. Data primer adalah hasil wawancara, data sekunder adalah putusan pengadilan dan sumber-sumber yang relevan dengan penelitian dan data tersier adalah data penunjang dari internet. Prosedur pengumpulan data dengan menggunakan obervasi, wawancara, studi pustaka dan dokumentasi, objek observasi dan wawancara pada penelitian ini adalah Penyidik dari Polres Bantul dan Hakim Pengadilan Negeri Bantul. Studi pustaka untuk mencari data tambahan dari peraturan perundang-undangan yang berhubungan dengan objek penelitian dan sumber-sumber yang relevan. Dokumentasi dengan alat perekam dan kamera. Teknik analisis data yang digunakan adalah dengan mereduksi data yang diperoleh, kemudian menyajikan data yang mempunyai hubungan 
dengan judul penelitian. Keabsahan data menggunakan triangulasi teknik untuk menguji kredibilitas data dan dilakukan dengan cara mengecek data kepada sumber yang berbeda dengan teknik yang sama.

\section{HASIL PENELITIAN DAN PEMBAHASAN}

Fakta hukum yang telah terungkap di persidangan majelis hakim mempertimbangkan perbuatan pelaku pembakaran mayat tersebut memenuhi unsur unsur dari pasal sebagaimana yang didakwakan jaksa penuntut umum kepada pelaku. Dari 3 pasal yang di dakwakan oleh penuntut umum, majelis hakim menjatuhkan putusan yang melanggar yaitu Pasal 170 ayat 1 KUHP. Alasan pelaku yang pada awalnya hanya berniat untuk menjalankan wasiat dari korban untuk mengkremasi jenasahnya, dan pelaku tidak mengetahui bahwa perbuatannya telah melanggar hukum, bahwa alasan tersebut tidak diterima karena merujuk pada fiksi hukum, yang terdapat dalam UU No 12 tahun 2011 bahwa agar setiap orang mengetahuinya, memerintahkan pengundangan Undang-Undang ini dengan penempatannya dalam Lembaran Negara Republik Indonesia.

Artinya ketika peraturan perundang-undangan sudah diundangkan maka semua warga negara dianggap tahu, termasuk warga negara yang buta aksara, warga negara yang tidak bisa mengakses undang-undang tersebut pun tetap dianggap tahu dan ketika melanggar aturan perundang-undangan akan tetap dihukum sesuai aturan yang sudah diterapkan. Sehingga alasan Ignorantia Legis Excusat Neminem (ketidaktahuan tentang hukum) bukan alasan untuk meringankan pidana pelaku dan bukan alasan untuk memaafkan pelaku.

Vonis hakim adalah Pasal 170 ayat 1 KUHP, karena bukti-bukti yang diserahkan lebih kuat, dibandingkan pasal yang lainnya. Vonis bersalah dijatuhkan hakim kepada pelaku pembakaran mayat karena terbukti perbuatan pelaku memenuhi unsur-unsur dalam Pasal 170 ayat 1 KUHP. Di dalam kasus pembakaran mayat ini, hakim memberikan keringanan karena dengan alasan anak korban tidak ada yang merawat, tetapi walaupun diberi keringanan pelaku tetap menjalankan prosedur hukum, dan ditahan selama 5 bulan penjara. Alasan pemaaf yaitu apabila pelaku tidak mampu mempertanggungjawabkan perbuatannya misalnya pelaku adalah orang gila atau orang yang cacat mental. Sedangkan alasan pembenar adalah alasan yang menghilangkan 
pidana yang disebabkan terdakwa dibenarkan, misalnya overmach, perbuatan terdakwa berdasarkan perintah atasan atau bahwa perbuatan terdakwa karena perintah undangundang. Vonis yang dijatuhkan hakim dalam perkara putusan no 15/Pid.B / 2019 / PN Btl, adalah vonis bersalah dengan hukuman pidana penjara selama 5 bulan karena telah terbukti secara sah dan meyakinkan bersalah melakukan tindak pidana kekerasan yang dilakukan secara bersama - sama terhadap orang dan barang di muka umum, yang dimana terkhususkan telah di atur pada pasal 170 ayat (1) KUHP. Jadi bukan unsur Ignorantia Legis Excusat Neminem yang dapat meringankan dakwaan untuk pelaku.

Kasus pembakaran mayat yang terjadi di Sanden Bantul ini merupakan salah satu kasus yang berpangkal dari ketidaktahuan seseorang tentang hukum atau Ignorantia Legis Excusat Nemiem oleh masyarakat. Dapat terlihat bahwa penyebarluasan dari peraturan perundang-undangan di Indonesia belum semuanya menyentuh lapisan masyarakat. Artinya ketidaktahuan hukum tidak bisa dimaafkan. Seseorang tidak bisa mengelak dari jeratan hukum dengan berdalih belum atau tidak mengetahui adanya hukum dan peraturan perundang-undangan tertentu. Teori fiksi hukum yang menganggap semua orang tahu hukum diimplementasikan dalam UU No 11 Tahun 2012 pasal 81 yang berbunyi "agar setiap orang mengetahuinya", peraturan perundangundangan harus diundangkan dengan menempatkannya dalam lembaran negara republik indonesia, tambahan lembaran negara republik indonesia, berita negara republik indonesia, tambahan berita negara republik indonesia, lembaran daerah, tambahan lembaran daerah dan berita daerah.

Melibatkan masyarakat dalam perumusan peraturan perundang-undangan juga tentunya perlu mendapat perhatian, manakala banyak kasus-kasus yang terjadi karena alasan ketidaktahuan hukum (ignorantian legis excusat neminem) oleh masyarakat. Mengingat juga bahwa hukum yang ada harus sesuai dengan budaya hukum masyarakat setempat jika memang hukum tersebut dapat berlaku secara efektif. Begitupun ketika suatu peraturan perundang-undangan telah ditetapkan, kemudian disahkan dan diundangkan sesuai dengan prosedur yang berlaku. Dalam hal ini aspek sosialisasi hukum menjadi sangat penting, terutama badan-badan yang berwenang untuk menyebarluaskan peraturan perundang-undangan di tengah-tengah masyarakat. Tujuannya agar tercipta masyarakat yang paham dan patuh hukum, sehingga kasuskasus yang berpangkal dari ketidaktahuan hukum dapat diminimalisir dan tidak terulang kembali. 


\section{SIMPULAN}

Berdasarkan hasil penelitian dan pembahasan terhadap kasus pembakaran mayat yang terjadi di Sanden Bantul maka dapat ditarik kesimpulan dari permasalahan serta memberikan sumbangsih pemikiran berupa saran terkait permasalahan diatas. Oleh karena itu dari uraian skripsi ini diambil kesimpulan dengan dalih ketidaktahuannya tentang hukum, bahwa pelaku tidak mengetahui perbuatannya telah melanggar hukum dan hanya menjalankan wasiat dari korban, maka alasan tersebut tidak dapat membebaskan pelaku dari tuntutan hukum. Dari kasus pembakaran mayat tersebut telah memenuhi unsur-unsur yang terdapat dalam Pasal 170 ayat 1 KUHP dan pelaku dihukum 5 bulan penjara. Unsur ignorantia legis excusat neminem tidak bisa menjadi alasan untuk membebaskan dan meringankan pelaku dari tuntutan hukum. Kecuali pelaku adalah orang yang tidak bisa mempertanggungjawabkan perbuatannya seperti orang yang cacat mental atau orang gila. Adanya unsur di luar non hukum yaitu kekuasaan hakim yang dapat meringankan masa tahanan pelaku, dengan menggunakan sisi kemanusiaannya. Berdasarkan penelitian, fiksi hukum tentang penyebarluasan peraturan perundang-undangan belum maksimal, sehingga perlu mendapat perhatian dari berbagai pihak, supaya tidak ada lagi kasus yang berpangkal dari ketidaktahuan masyarakat tentang hukum yang berlaku.

\section{Saran}

1. Kepada pemerintah dan pihak-pihak yang berwenang dalam penyebarluasan peraturan perundang-undangan, perlunya sosialisasi secara menyeluruh tentang peraturan perundang-undangan baik sebelum maupun sesudah diundangan. Selain itu mengingat banyaknya peraturan perundang-undangan, disarankan agar proses publikasi atau penyebarluasan dilakukan secara selektif.

2. Kepada masyarakat luas agar menyeimbangkan tentang penyebarluasan peraturan perundang-undangan agar tetap harus mencari tahu tentang aturan-aturan yang ada di negaranya. Sehingga program pemerintah berupa penyebarluasan aturan perundang-undangan berjalan lancar dan sukses. Sehingga tercipta masyarakat yang paham dan melek hukum.

3. Kepada mahasiswa-mahasiswa PPKn sebagai sarjana ilmu Pendidikan Kewarganegaraan, kita mempunyai amanah untuk ikut serta menyebarluaskan peraturan perundang-undangan dimulai dari diri kita sendiri, keluarga, mengadakan sosialisasin sadar hukum. Agar masyarakat menjadi lebih paham dan mencintai negaranya dan tidak berbuat melanggar hukum. 


\section{DAFTAR PUSTAKA}

Aloysius R. Entah. 2016. "Indonesia: Negara Hukum yang Berdasarkan Pancasila". Jurnal Ilmu Hukum, (Online), Volume 2, No 1, (https://journal.unnes. ac.id/sju/index.php/snh/article/../10079/, diunduh 27 Desember 2018).

Andi Anugra. 2013. Tinjauan Yuridis Terhadap Tindak Pidana Pembakaran Yang

Dapat Membahayakan Keamanan Umum Bagi Orang Dan Barang. Skripsi. Makasar: Departemen Hukum Pidana Fakultas Hukum. Universitas Hasanuddin Makassar.

Haposan Siallagan. 2016. "Penerapan Prinsip Negara Hukum Di Indonesia". Jurnal Ilmu Hukum, (Online), Volume 18, No. 2, (https://jurnal.unpad. ac.id/sosiohumaniora/article/view/9947, diunduh 27 Desember 2018).

Heppi Florensia dan Mety Rahmawati. 2018. "Pemidanaan Terhadap Perbuatan Menghilangkan Mayat Yang Dilakukan Anak (Studi Terhadap Putusan Mahkamah Agung No. 774k / Pid.Sus / 2015)”. Jurnal Hukum Adigama, (Online), Volume 1, No. 1, (https://journal.untar.ac.id, diunduh 11 Mei 2019).

Rahmat Setiabudi Sokonagoro, dkk. 2008. "Menggali Peristilahan Hukum Dalam Bahasa Hukum Indonesia”, (Online),(http://khtibwriteinc.blogspot.com/ 2008/ 03/menggali-makna-peristilahan-hukum-dalam.html, diunduh 29 Desember 2018.

Ronny Hanijito Soemito. 2001. Metodologi Penelitian Hukum dan Jurimetri. Jakarta : Ghaia Indonesia.

Soenarto Soerodibroto. 2019. KUHP Dan KUHAP Dilengkapi Yurispridensi Mahkamah Agung Dan Hoge Raad. Jakarta: Raja Grafindo Persada.

Sudaryono dan Natangsa Subakti. 2005. Hukum Pidana (Buku Pegangan Kuliah). Surakarta: Fakultas Hukum UMS.

Thomas Susanto. 2002. Teori-teori Kekerasan. Jakarta : Ghalia Indonesia.

Wirjono Prodjodikoro. 2003. Tindak-Tindak Pidana Tertentu di Indonesia. Bandung: Refika Aditama. 